\title{
Short communication: Effect of oilseed supplementation of an herbage diet on ruminal fermentation in continuous culture
}

\author{
K. J. Soder, ${ }^{* 1}$ A. F. Brito, $†$ and M. D. Rubano* \\ *USDA-Agricultural Research Service, Pasture Systems and Watershed Management Research Unit, University Park, PA 16802 \\ †Department of Biological Sciences, University of New Hampshire, Durham 03824
}

\section{ABSTRACT}

A 4-unit continuous culture fermentor system was used to evaluate the effects of oilseed supplementation of an herbage-based diet on nutrient digestibility, fermentation profile, and bacterial nitrogen $(\mathrm{N})$ synthesis. Treatments were randomly assigned to fermentors in a $4 \times 4$ Latin square design with $7 \mathrm{~d}$ for diet adaptation and $3 \mathrm{~d}$ for data and sample collection. Dietary treatments were an herbage-only diet (HERB), or the following ground oilseeds supplemented to an herbagebased diet at $10 \%$ of total dry matter (DM) fed: flaxseed (FLAX), canola (CAN), or sunflower (SUN). Apparent $\mathrm{DM}$, organic matter, and neutral detergent fiber digestibility were not affected by diet, averaging 62,68 , and $78 \%$, respectively. True DM and organic matter digestibility were not affected by diet, averaging 78 and $82 \%$, respectively. Fermentor $\mathrm{pH}$ and total volatile fatty acids were not affected by diet. Branched-chain volatile fatty acids tended to be lower for HERB compared with the 3 oilseed diets. Ammonia N concentrations were lowest for the HERB diet. Crude protein digestibility was not affected by diet. Flow of $\mathrm{NH}_{3}-\mathrm{N}$ was lowest for the HERB diet reflecting the lowest culture concentration of $\mathrm{NH}_{3}-\mathrm{N}$. Bacterial $\mathrm{N}$ flows were lowest for HERB and SUN diets, intermediate for FLAX, and greatest for CAN. Flows of total N, non- $\mathrm{NH}_{3}-\mathrm{N}$, and dietary $\mathrm{N}$ were not affected by diet. Likewise, efficiency of bacterial $\mathrm{N}$ synthesis was not affected by diet. Supplementation with FLAX, CAN, or SUN at 10\% of total DM fed did not affect nutrient digestibility or ruminal fermentation compared with an all-herbage diet. The oilseeds tested herein may be considered as alternative energy supplements for grazing dairy cows, particularly during times of low availability of corn. However, in vivo studies are needed to further evaluate the effects of oilseeds supplementation of an herbage-based diet on milk production and composition (specifically human-beneficial fatty acids).

Key words: herbage, in vitro fermentation, oilseed

Received November 27, 2012.

Accepted December 8, 2012.

${ }^{1}$ Corresponding author: kathy.soder@ars.usda.gov

\section{Short Communication}

Oilseeds have been used as a supplemental source of fat in dairy rations in an attempt to improve energy supply while modifying milk FA profile. For instance, the milk concentration of functional lipids such as conjugated linoleic acids (CLA; Glasser et al., 2008) and n-3 FA (Larsen et al., 2012) generally increases when feeding oilseeds, particularly flaxseed (Linum usitatissimum). Recent literature reviews (McCrorie et al., 2011; Dilzer and Park, 2012) have documented a variety of potential health benefits to humans attributed mostly to the cis-9,trans-11 and trans-10,cis-12 isomers of CLA, such as reduced body fat, cardiovascular diseases, and cancer, as well as modulation of immune and inflammatory responses. Likewise, it is now recognized that n-3 FA are essential for normal growth, brain development, vision, and immunity in infants, and have been linked to prevention and treatment of cardiovascular diseases (Williams, 2000). It is important to note, however, that further research, specifically clinical studies with defined subject characteristics, experimental durations, and FA doses, is needed to elucidate the role of these functional lipids (e.g., CLA and n-3 FA) on preventing chronic diseases in humans (McCrorie et al., 2011; Dilzer and Park, 2012).

Because of current high prices and reduced availability of corn combined with the potential health benefits attributed to CLA and n-3 FA, interest is growing in feeding oilseeds as the sole energy supplement source on grazing dairy farms. Both milk FA profile and ruminal fermentation responses to oilseeds may vary based on the composition of the basal diet (Chilliard et al., 2007; Glasser et al., 2008), level and type of oilseed supplementation (Glasser et al., 2008; Beauchemin et al., 2009; Soder et al., 2012), and method of oilseed processing (Gonthier et al., 2004, 2005; da Silva et al., 2007; Martin et al., 2008). However, most of this previous research was conducted with confined dairy cows fed conserved forages incorporated into TMR diets. Furthermore, direct comparisons of various oilseeds on ruminal fermentation and bacterial protein synthesis are limited, particularly when supplemented to an herbage-based diet. Therefore, the objective of this 
study was to evaluate the effects of replacing orchardgrass (Dactylis glomerata L.) herbage (HERB) with 3 different oilseeds (flaxseed, FLAX; canola seed, CAN; or sunflower seed, SUN) on ruminal fermentation, apparent nutrient digestibility, and nitrogen $(\mathrm{N})$ metabolism during continuous culture fermentation. We hypothesize that replacing herbage with oilseeds will change culture fermentation profile due to enhanced supply of dietary unsaturated FA, which can affect nutrient digestibility and bacterial protein synthesis.

This study was conducted at the USDA-ARS Pasture Systems and Watershed Management Research Unit (University Park, PA), from January to April 2011. Each fermentor was fed a total of $70 \mathrm{~g}$ of DM/d of 1 of 4 diets: $100 \%$ HERB, or orchardgrass herbage plus 1 of 3 oilseeds (FLAX, CAN, or SUN) supplemented at a rate of $10 \%$ of total DM fed. Oilseeds and herbage were ground to pass through a 2-mm screen. Each fermentor received herbage in 4 equal feedings at 0730, 1030, 1400 and $1900 \mathrm{~h}$. The oilseed treatments were fed twice daily in equal amounts at 0730 and $1400 \mathrm{~h}$. The study was a $4 \times 4$ Latin square design with each dual-flow continuous culture fermentation unit receiving each treatment once over the 4 periods. The continuous culture fermentor system, sample collection, and analyses were conducted per the methods of Soder et al. (2012). Herbage, oilseeds, and effluent were analyzed by wet chemistry (DairyOne Laboratories, Ithaca, NY) according to the following methods: DM (method 930.15; AOAC International, 2006), CP (method 990.03; AOAC International, 2006), NDF (Van Soest et al., 1991), watersoluble carbohydrates, ethanol-soluble carbohydrates (Hall et al., 1999), starch (Application Note Number 319; YSI Inc. Life Sciences, Yellow Springs, Ohio), and ether extract (method 2003.06; AOAC, 2006). The RDP was determined using the procedures of Coblentz et al. (1999). The concentration of NSC was calculated by adding water-soluble carbohydrates plus starch. Concentrations of total purines (Zinn and Owens, 1986) in effluent and bacterial isolates were used to partition effluent $\mathrm{N}$ flow into bacterial and non-bacterial fractions and to calculate true DM and OM digestibilities and flows.

Data were analyzed as a $4 \times 4$ Latin square design using the GLM procedure of SAS (SAS Institute Inc., Cary, NC). The model included the fixed effects of treatment and period, the random effect of fermentor, and the residual error. Least squares means and SEM are reported for all data. Significance was declared at $P<0.05$ and trends between $P>0.05$ and $P<0.10$. Apparent nutrient digestibility and nutrient flows were calculated per the equations used in Soder et al. (2012).

Nutrient compositions of the herbage, supplements, and the experimental diets are presented in Table 1. The use of pooled samples for compositional analysis precluded statistical comparison of treatments. The level of fat in all diets was within NRC (2001) recommendations for dairy diets, that is, an upper limit of 3 to $4 \%$ added fat and 6 to $7 \%$ of total fat in the dietary DM. In general, the nutrient composition of all 4 experimental diets was very similar due to the low dietary inclusion ( $10 \%$ of the diet DM) of oilseeds despite some differences in nutrient profile of the individual oilseeds.

Apparent digestibilities of DM, OM, and NDF were not affected by diet, averaging 62,68 , and $78 \%$, respectively (Table 2). Likewise, true DM and OM digestibilities were not affected by replacing herbage with oilseeds, averaging 78 and $82 \%$, respectively (Table 2 ). The current results agree with those of Gonthier et al. (2004), who showed in lactating dairy cows no effect of different forms (i.e., raw, micronized, or extruded) of flaxseed (supplemented at $12.6 \%$ of diet DM) on ruminal digestibilities of DM, OM, NDF, CP, FA, and gross energy compared with the control (no supple-

Table 1. Chemical composition (\% of DM) of a 100\% herbage diet (HERB) or an herbage diet supplemented with either $10 \%$ flaxseed (FLAX), canola (CAN), or sunflower seed (SUN) during continuous culture fermentation

\begin{tabular}{|c|c|c|c|c|c|c|c|}
\hline \multirow[b]{2}{*}{ Item } & \multicolumn{3}{|c|}{ Ingredient } & \multicolumn{4}{|c|}{$\operatorname{Diet}^{1}$} \\
\hline & Flaxseed & Canola & Sunflower & HERB & FLAX & $\mathrm{CAN}$ & SUN \\
\hline $\mathrm{OM}$ & 89.7 & 91.7 & 93.9 & 93.6 & 93.2 & 93.4 & 93.6 \\
\hline $\mathrm{CP}$ & 21.4 & 24.7 & 23.3 & 22.1 & 22.0 & 22.4 & 22.2 \\
\hline RDP, $\%$ of $\mathrm{CP}$ & 69.0 & 65.0 & 68.0 & 74.0 & 73.5 & 73.1 & 73.4 \\
\hline NDF & 23.1 & 31.7 & 38.1 & 54.2 & 51.1 & 52.0 & 52.6 \\
\hline $\mathrm{WSC}^{2}$ & 4.2 & 8.0 & 4.8 & 10.9 & 10.2 & 10.6 & 10.3 \\
\hline $\mathrm{ESC}^{2}$ & 3.5 & 7.4 & 4.5 & 9.3 & 8.7 & $\begin{array}{r}10.0 \\
9.1\end{array}$ & 8.8 \\
\hline Starch & 0.5 & 0.3 & 0.1 & 1.7 & 1.6 & 1.6 & 1.5 \\
\hline $\mathrm{NSC}$ & 4.7 & 8.3 & 4.9 & 12.6 & 11.8 & 12.2 & 11.8 \\
\hline Ether extract & 20.7 & 37.5 & 41.8 & 3.5 & 5.2 & 6.9 & 7.3 \\
\hline
\end{tabular}

${ }^{1}$ Calculated using actual nutrient composition and proportion of individual ingredients.

${ }^{2} \mathrm{WSC}=$ water soluble carbohydrate; ESC $=$ ethanol soluble carbohydrate. 
mental fat). Scholljegerdes and Kronberg (2010) found that supplementing ground flaxseed to beef cattle grazing summer native rangelands on the northern Great Plains causes no changes in ruminal NDF digestibility compared with the control (grazing only) or corn/soybean meal-based supplemented diets, which agrees with current and previous research (Gonthier et al., 2004). Aldrich et al. (1997a) observed no detrimental effect on apparent total tract digestibility of nutrients (e.g., DM, $\mathrm{OM}, \mathrm{CP}, \mathrm{NDF}, \mathrm{ADF}$, and gross energy) when feeding (11\% of diet DM) lactating dairy cows diets containing canola seed (treated or crushed) or calcium salts of long-chain FA. Compared with switchgrass (Panicum virgatum) hay only, canola seed supplementation ( $8 \%$ of diet DM) fed as whole or ground did not affect the apparent total-tract digestibility of $\mathrm{OM}, \mathrm{NDF}$, and $\mathrm{ADF}$ in steers (Leupp et al., 2006).

Conversely, Beauchemin et al. (2009) reported that feeding lactating dairy cows a commercial source of calcium salts of long-chain FA or different crushed oilseeds decreases $(P<0.05)$ apparent total-tract digestibilities of DM and OM, ranging from 8 to $20 \%$ when flaxseed or sunflower seed-but not canola seed - were added to the diet at a rate of 9 to $10 \%$ of total DMI. Both Hussein et al. (1995) and Aldrich et al. (1997b) reported no differences in ruminal digestibility of OM with feeding ( $10 \%$ of the diet DM) diets supplemented with canola seed versus no-canola seed to steers, which corroborate present results. However, apparent total-tract digestibility of OM was significantly reduced in these 2 studies (Hussein et al., 1995; Aldrich et al., 1997b) possibly as a result of greater variability associated with ruminal digestibility measurements compared with those of total tract or low digestibility of the seed coat as indicated by the authors. Martin et al. (2008) found that feeding (\% of diet DM) linseed as crude (12.4\%), extruded + wheat $(21.2 \%)$, or oil $(5.8 \%)$ to lactating dairy cows led to significant depression in the apparent total-tract digestibilities of DM, OM, and NDF compared with the control diet (no supplemental fat). Recently, we (Soder et al., 2012) reported linear decreases in the apparent digestibilities of DM, OM, and NDF, as orchardgrass herbage was replaced by incremental dietary levels (0 to $15 \%$ of total DM fed) of ground flaxseed during continuous culture fermentation. In general, discrepancies in the literature regarding the effect of oilseeds on nutrient digestibility may be explained by differences in the amount of supplemental fat, ingredient composition of the basal diet, animal type (steers vs. dairy cows), and processing methods. It must be also emphasized that in the controlled conditions of in vitro systems, there is no absorption of nutrients, $\mathrm{NH}_{3}$ or VFA was noted, which are important factors influencing ruminal nutrient digestibility. Therefore, in vitro vs. in vivo studies should be interpreted cautiously to avoid bias.

Mean, minimum, and maximum $\mathrm{pH}$ were not affected by diet, averaging $6.77,6.59$ and 7.00 , respectively (Table 2). Lack of a dietary effect of supplemental fat on $\mathrm{pH}$ is in agreement with previous in vivo (Beauchemin et al., 2009) and in vitro research (Soder et al., 2012). Concentrations of total VFA were not affected by diet, averaging $64.3 \mathrm{mmol} / \mathrm{L}$ (Table 3). Molar proportions of individual VFA were not affected by diet; the branched-chain VFA isobutyrate and isovalerate tended $(P=0.09)$ to be lower for the HERB diet. The branched-chain VFA arise primarily from ruminal catabolism of branched-chain AA (Hoover, 1986) and diets containing oilseeds may have provided more RDP from preformed AA and peptides than the HERB diet. For instance, ruminal isobutyrate in lactating dairy cows was significantly higher in diets containing true protein sources (e.g., solvent soybean meal, cottonseed meal, or canola meal) versus an NPN source (e.g., urea) due to enhanced supply of RDP from preformed AA and peptides than RDP from $\mathrm{NH}_{3}-\mathrm{N}$ (Brito and Broderick, 2007).

Table 2. Nutrient digestibility and $\mathrm{pH}$ of a $100 \%$ herbage diet (HERB) or an herbage diet supplemented with either 10\% flaxseed (FLAX), canola (CAN), or sunflower seed (SUN) during continuous culture fermentation

\begin{tabular}{lcccccc}
\hline & \multicolumn{7}{c}{ Diet } \\
\cline { 2 - 4 } Item & HERB & FLAX & CAN & SUN & SEM & $P$-value \\
\hline Apparent digestibility & & & & & \\
DM, \% & 65.3 & 62.3 & 60.5 & 60.6 & 1.82 & 0.30 \\
OM, \% & 70.8 & 68.0 & 66.3 & 66.5 & 1.75 & 0.33 \\
NDF, \% & 79.4 & 81.3 & 73.8 & 76.1 & 2.12 & 0.20 \\
True digestibility & 78.4 & 78.6 & 78.8 & 75.8 & 1.42 & 0.45 \\
DM, \% & 82.6 & 82.9 & 83.1 & 80.8 & 1.36 & 0.63 \\
OM, \% & & & & & & 0.034 \\
pH & 6.75 & 6.72 & 6.77 & 6.85 & 0.14 \\
Mean & 6.60 & 6.52 & 6.60 & 6.62 & 0.028 & 0.19 \\
Minimum & 6.94 & 6.91 & 6.98 & 7.15 & 0.073 & 0.19 \\
Maximum & & & & & & \\
\hline
\end{tabular}


Table 3. Volatile fatty acid production of a 100\% herbage diet (HERB) or an herbage diet supplemented with either 10\% flaxseed (FLAX), canola (CAN), or sunflower seed (SUN) during continuous culture fermentation

\begin{tabular}{lcccccc}
\hline & \multicolumn{7}{c}{ Diet } & & \\
\cline { 2 - 5 } Item & HERB & FLAX & CAN & SUN & SEM & $P$-value \\
\hline Total VFA, mmol/L & 64.2 & 67.5 & 63.8 & 61.8 & 2.92 & 0.60 \\
mol/100 mol & & & & & & \\
Acetate (A) & 42.8 & 45.2 & 42.2 & 41.4 & 2.24 & 0.68 \\
Propionate (P) & 13.1 & 14.2 & 13.1 & 12.3 & 0.45 & 0.14 \\
Butyrate & 6.75 & 6.14 & 6.46 & 6.08 & 0.208 & 0.18 \\
Isobutyrate & 0.28 & 0.37 & 0.40 & 0.41 & 0.032 & 0.10 \\
Valerate & 1.25 & 1.44 & 1.36 & 1.28 & 0.104 & 0.615 \\
Isovalerate & 0.08 & 0.20 & 0.23 & 0.24 & 0.04 & 0.09 \\
A: P & 3.26 & 3.22 & 3.23 & 3.37 & 0.102 & 0.74 \\
\hline
\end{tabular}

The $\mathrm{NH}_{3}-\mathrm{N}$ concentration was lowest $(P<0.001)$ for the HERB diet, intermediate for the CAN diet, and greatest for the FLAX and SUN diets (Table 4). It is well known that herbage is rich in NPN, which can increase $\mathrm{NH}_{3}-\mathrm{N}$ formation in the rumen particularly in energy-deficient diets. For instance, the concentration of ruminal $\mathrm{NH}_{3}-\mathrm{N}$ decreased linearly when grazing cows received incremental levels of a ground dry-shelled corn-based concentrate (Reis and Combs, 2000). In the present study, however, $\mathrm{NH}_{3}-\mathrm{N}$ concentration was lowest with feeding HERB despite similar concentrations of CP across the 4 diets. Nitrogen and NSC degradation rates were, respectively, 63 and $69 \%$ higher in herbage than ground shelled corn-based concentrate (Kolver et al., 1998). Assuming higher N and NSC degradation rates in the HERB versus the oilseed diets, we hypothesized that $\mathrm{NH}_{3}-\mathrm{N}$ from RDP was synchronously released with fermentable energy from NSC resulting in enhanced capture of $\mathrm{NH}_{3}-\mathrm{N}$ with feeding HERB. Previous research (Kolver et al., 1998) showed that peak ruminal $\mathrm{NH}_{3}-\mathrm{N}$ concentration at 3 and $5 \mathrm{~h}$ after herbage feeding in the morning was reduced $(P<0.05)$ by approximately $33 \%$ when grazing dairy cows were fed a ground shelled corn-based concentrate synchronously (at 0900 and $1700 \mathrm{~h}$ ) rather than asynchronously (1300 and $2100 \mathrm{~h}$ ) with herbage. Furthermore, ruminal bacteria from late-lactation dairy cows fed p.m.-cut alfalfa baleage, with NSC concentration (12.8\% diet DM) similar to the current study captured more $\mathrm{NH}_{3}-\mathrm{N}(P<$ 0.01) than with feeding a.m.-cut alfalfa baleage (NSC $=10.5 \%$ DM basis), likely as a result of enhanced supply of fermentable energy with the former versus the latter forage diet (Brito et al., 2009). Beauchemin et al. (2009) observed that supplementing a silage-based diet with crushed sunflower seed significantly increased the ruminal concentration of $\mathrm{NH}_{3}-\mathrm{N}$ compared with the control (calcium salts of long-chain FA), crushed flaxseed, or crushed canola seed diets. Those authors (Beauchemin et al., 2009) speculated that the highest concentration of ruminal $\mathrm{NH}_{3}-\mathrm{N}$ with the sunflower diet was caused by reduced digestible $\mathrm{OM}$ in the rumen resulting in decreased bacterial uptake of $\mathrm{NH}_{3}-\mathrm{N}$. However, increased concentration of $\mathrm{NH}_{3}-\mathrm{N}$ with feeding FLAX and SUN diets in the current study appears to be independent of apparent and true OM digestibilities, which were similar across the 4 treatments (Table 2).

Apparent CP digestibility was not affected by diet, averaging $85 \%$ across the 4 treatments (Table 4 ). Flow of $\mathrm{NH}_{3}-\mathrm{N}$ was lowest $(P=0.002)$ for the HERB diet reflecting the lowest concentration of culture $\mathrm{NH}_{3}-\mathrm{N}$ with this treatment. Flow of bacterial $\mathrm{N}$ was lowest $(P<0.05)$ for the HERB and SUN diets, intermediate for the FLAX diet, and greatest for the CAN diet. Concentration of $\mathrm{NH}_{3}-\mathrm{N}$ across all 4 diets was well above the minimium range ( 5 to $8 \mathrm{mg} / \mathrm{dL}$ ) known to impair bacterial growth (Satter and Slyter, 1974; Kang-Meznarich and Broderick, 1980; Brito and Broderick, 2006). Therefore, $\mathrm{NH}_{3}-\mathrm{N}$ concentration does not explain differences in bacterial $\mathrm{N}$ flow in the present study. Histidine appears to be the first limiting AA in dairy cows fed grass silage-based diets (Korhonen et al., 2000). Assuming His is also the first limiting AA in herbage-based diets containing orchardgrass, supplementation with canola, a rich source of His (Kendall et al., 1991; Rode and Kung, 1996), and other essential AA (Piepenbrink and Schingoethe, 1998) may explain the observed increase in bacterial $\mathrm{N}$ flow (Table 4). Supplementing poor quality switchgrass hay with canola (ground or whole) significantly increased the duodenal flow of bacterial OM in Holstein steers (Leupp et al., 2006). Because nutrient intake did not differ across treatments (Leupp et al., 2006), it can be hypothesized that enhanced supply of RDP or essential AA - particularly His - explains the observed increase in bacterial OM synthesis reported earlier (Leupp et al., 2006). Flows of total N, non- $\mathrm{NH}_{3}-\mathrm{N}$, and dietary $\mathrm{N}$ were not affected by diet, averaging 1.81, 1.22, and 0.37 $\mathrm{mg} / \mathrm{d}$, respectively. Likewise, efficiency of bacterial $\mathrm{N}$ 
Table 4. Nitrogen metabolism of a 100\% herbage diet (HERB), or an herbage diet supplemented with either $10 \%$ flaxseed (FLAX), canola (CAN), or sunflower seed (SUN) during continuous culture fermentation

\begin{tabular}{|c|c|c|c|c|c|c|}
\hline \multirow[b]{2}{*}{ Item } & \multicolumn{4}{|c|}{ Diet } & \multirow[b]{2}{*}{ SEM } & \multirow[b]{2}{*}{$P$-value } \\
\hline & HERB & FLAX & CAN & SUN & & \\
\hline $\mathrm{NH}_{3}-\mathrm{N}, \mathrm{mg}$ of $\mathrm{N} / \mathrm{dL}$ & $15.7^{\mathrm{a}}$ & $20.9^{\mathrm{b}}$ & $19.5^{\mathrm{c}}$ & $21.0^{\mathrm{b}}$ & 0.35 & $<0.001$ \\
\hline $\mathrm{CP}$ digestibility, \% & 84.1 & 85.8 & 86.9 & 84.1 & 1.60 & 0.57 \\
\hline \multicolumn{7}{|l|}{$\mathrm{N}$ flows, $\mathrm{mg} / \mathrm{d}$} \\
\hline Total N & 1.72 & 1.80 & 1.91 & 1.82 & 0.603 & 0.25 \\
\hline $\mathrm{NH}_{3}-\mathrm{N}$ & $0.51^{\mathrm{a}}$ & $0.66^{\mathrm{b}}$ & $0.63^{\mathrm{b}}$ & $0.66^{\mathrm{b}}$ & 0.017 & 0.002 \\
\hline Non- $\mathrm{NH}_{3}-\mathrm{N}$ & 1.21 & 1.21 & 1.28 & 1.16 & 0.043 & 0.34 \\
\hline Bacterial N & $0.81^{\mathrm{a}}$ & $0.86^{\mathrm{ab}}$ & $0.95^{\mathrm{b}}$ & $0.77^{\mathrm{a}}$ & 0.033 & 0.03 \\
\hline Dietary N & 0.39 & 0.35 & 0.33 & 0.40 & 0.040 & 0.59 \\
\hline $\begin{array}{l}\text { Bacterial efficiency } \\
\text { mg of bacterial N/kg of OM truly } \\
\text { digested }\end{array}$ & 15.1 & 15.8 & 17.5 & 14.5 & 0.84 & 0.16 \\
\hline
\end{tabular}

${ }^{\mathrm{a}-\mathrm{c}}$ Means within the same row with different superscripts differ at $P<0.05$.

synthesis was not affected by diet averaging $15.7 \mathrm{mg}$ of bacterial $\mathrm{N} / \mathrm{kg}$ of $\mathrm{OM}$ truly digested.

In conclusion, supplementation with oilseeds (i.e., ground flaxseed, canola seed or sunflower seed) at $10 \%$ of total DM fed did not negatively affect nutrient digestibility and only slightly affected culture fermentation compared with an all-herbage diet. Replacing herbage (HERB diet) with canola seed (CAN diet) resulted in the greatest flow of bacterial $\mathrm{N}$, suggesting that this supplementation strategy may improve yields of milk and milk protein. We conclude that flaxseed, canola seed, and sunflower seed may be considered as potential alternative energy supplements for grazing dairy cows, particularly during times of low availability of corn. However, in vivo studies are needed to further evaluate the effects of supplementing herbage-based diets with flaxseed, canola seed, and sunflower seed on milk production and composition (particularly beneficial FA such as CLA and n-3 FA) as well as animal health.

\section{REFERENCES}

Aldrich, C. G., N. R. Merchen, J. K. Drackley, G. C. Fahey Jr., and L. L. Berger. 1997a. The effects of chemical treatment of whole canola seed on intake, nutrient digestibilities, milk production, and milk fatty acids of Holstein cows. J. Anim. Sci. 75:512-521.

Aldrich, C. G., N. R. Merchen, J. K. Drackley, S. S. Gonzalez, G. C. Fahey Jr., and L. L. Berger. 1997b. The effects of chemical treatment of whole canola seed on lipid protein digestion by steers. J. Anim. Sci. 75:502-511.

AOAC International. 2006. Official Methods of Analyses, 18th ed. AOAC International, Gaithersburg, MD.

Beauchemin, K. A., S. M. McGinn, C. Benchaar, and L. Holtshausen. 2009. Crushed sunflower, flax, or canola seeds in lactating dairy cow diets: Effects on methane production, rumen fermentation, and milk production. J. Dairy Sci. 92:2118-2127.

Brito, A. F., and G. A. Broderick. 2006. Effects of varying dietary ratios of alfalfa silage to corn silage on production and nitrogen utilization in lactating dairy cows. J. Dairy Sci. 89:3924-3938.

Brito, A. F., and G. A. Broderick. 2007. Effects of different protein supplements on milk production and nutrient utilization in lactating dairy cows. J. Dairy Sci. 90:1816-1827.
Brito, A. F., G. F. Tremblay, H. Lapierre, A. Bertrand, Y. Castonguay, G. Belanger, R. Michaud, C. Benchar, D. R. Ouellet, and R. Berthiaume. 2009. Alfalfa cut at sundown and harvested as baleage increases bacterial protein synthesis in late-lactation dairy cows. J. Dairy Sci. 92:1092-1107.

Chilliard, Y., F. Glasser, A. Ferlay, L. Bernard, J. Rouel, and M. Doreau. 2007. Diet, rumen biohydrogenation and nutritional quality of cow and goat milk fat. Eur. J. Lipid Sci. Technol. 109:828855

Coblentz, W. K., I. E. O. Abdelgadir, R. C. Cochran, J. O. Fritz, W. H. Fick, K. C. Olson, and J. E. Turner. 1999. Degradability of forage proteins by in situ and in vitro enzymatic methods. J. Dairy Sci. 82:343-354.

da Silva, D. C., G. T. Santos, A. F. Branco, J. C. Damasceno, R. Kazama, M. Matsushita, J. A. Horst, W. B. R. dos Santos, and H. V. Petit. 2007. Production performance and milk composition of dairy cows fed whole or ground flaxseed with or without monensin. J. Dairy Sci. 90:2928-2936.

Dilzer, A., and Y. Park. 2012. Implication of conjugated linoleic acid (CLA) in human health. Crit. Rev. Food Sci. Nutr. 52:488-513.

Glasser, F., A. Ferlay, and Y. Chilliard. 2008. Oilseed lipid supplements and fatty acid composition of cow milk: A meta-analysis. J. Dairy Sci. 91:4687-4703.

Gonthier, C., A. F. Mustafa, R. Berthiaume, H. V. Petit, R. Martineau, and D. R. Oullet. 2004. Effects of feeding micronized and extruded flaxseed on ruminal fermentation and nutrient utilization by dairy cows. J. Dairy Sci. 87:1854-1863.

Gonthier, C., A. F. Mustafa, D. R. Oullet, P. Y. Chouinard, R. Berthiaume, and H. V. Petit. 2005. Feeding micronized and extruded flaxseed to dairy cows: Effects on blood parameters and milk fatty acid composition. J. Dairy Sci. 88:748-756.

Hall, M. B., W. H. Hoover, J. P. Jennings, and T. K. Miller Webster. 1999. A method for partitioning neutral detergent-soluble carbohydrates. J. Sci. Food Agric. 79:2079-2086.

Hoover, W. H. 1986. Chemical factors involved in ruminal fiber digestion. J. Dairy Sci. 69:2755-2766.

Hussein, H. S., N. R. Merchen, and G. C. Fahey Jr.. 1995. Effects of forage level and canola seed supplementation on site and extent of digestion of organic matter, carbohydrates and energy by steers. J. Anim. Sci. 73:2458-2468.

Kang-Meznarich, J. H., and G. A. Broderick. 1980. Effects of incremental urea supplementation on ruminal ammonia concentration and bacterial protein formation. J. Anim. Sci. 51:422-431.

Kendall, E. M., J. R. Ingalls, and R. J. Boila. 1991. Variability in the rumen degradability and postruminal digestion of the dry matter, nitrogen and amino acids of canola meal. Can. J. Anim. Sci. 71:739-754.

Kolver, E., L. D. Muller, G. A. Varga, and T. J. Cassidy. 1998. Synchronization of ruminal degradation of supplemental carbohy- 
drate with pasture nitrogen in lactating dairy cows. J. Dairy Sci. 81:2017-2028.

Korhonen, M., A. Vanhatalo, T. Varvikko, and P. Huhtanen. 2000. Responses to graded postruminal doses of histidine in dairy cows fed grass silage diets. J. Dairy Sci. 83:2596-2608.

Larsen, M. K., L. Hymøller, D. B. Brask-Pedersen, and M. R. Weisbjerg. 2012. Milk fatty acid composition and production performance of Danish Holstein and Danish Jersey cows fed different amounts of linseed and rapeseed. J. Dairy Sci. 95:3569-3578.

Leupp, J. L., G. P. Lardy, S. A. Soto-Navarro, M. L. Bauer, and J. S. Caton. 2006. Effects of canola seed supplementation on intake, digestion, duodenal protein supply, microbial effciency in steers fed forage-based diets. J. Anim. Sci. 84:499-507.

Martin, C., J. Rouel, J. P. Jouany, M. Doreau, and Y. Chilliard. 2008. Methane output and diet digestibility in response to feeding dairy cows crude linseed, extruded linseed, or linseed oil. J. Anim. Sci. 86:2642-2650.

McCrorie, T. A., E. M. Keaveney, J. M. W. Wallace, N. Binns, and M. B. E. Livingstone. 2011. Human health effects of conjugated linoleic acid from milk and supplements. Nutr. Res. Rev. 24:206-227.

NRC. 2001. Nutrient requirements of dairy cattle. 7th rev. ed. Nat. Acad. Sci. Washington, D.C.

Piepenbrink, M. S., and D. J. Schingoethe. 1998. Ruminal degradation, amino acid composition, and estimated intestinal digestibilities of four protein supplements. J. Dairy Sci. 81:454-461.

Reis, R. B., and D. K. Combs. 2000. Effects of increasing levels of grain supplementation on rumen environment and lactation per- formance of dairy cows grazing grass-legume pasture. J. Dairy Sci. 83:2888-2898.

Rode, L. M., and L. Kung Jr. 1996. Rumen-protected amino acids improve milk production and milk protein yield. Pages 289-300 in Advances in Dairy Technol. Proc. Western Canadian Dairy Seminar, Red Deer, Alberta, Canada. J. J. Kennelly, ed. University of Alberta, Edmonton, Alberta, Canada.

Satter, L. D., and L. L. Slyter. 1974. Effect of ammonia concentration on rumen microbial protein production in vitro. Br. J. Nutr. $32: 199-208$.

Scholljegerdes, E. J., and S. L. Kronberg. 2010. Effect of supplemental ground flaxseed fed to beef cattle grazing summer native range on the northern Great Plains. J. Anim. Sci. 88:2108-2121.

Soder, K. J., A. F. Brito, M. D. Rubano, and C. J. Dell. 2012. Effect of incremental flax supplementation of an herbage diet on methane output and ruminal fermentation in continuous culture. J. Dairy Sci. 95:3961-3969.

Van Soest, P. J., J. B. Robertson, and B. A. Lewis. 1991. Methods for dietary fiber, neutral detergent fiber and non-starch polysaccharides in relation to animal nutrition. J. Dairy Sci. 74:3583-3597.

Williams, C. M. 2000. Dietary fatty acids and human health. Ann. Zootech. 49:165-205.

Zinn, R. A., and F. N. Owens. 1986. A rapid procedure for purine measurement and its use for estimating net ruminal protein synthesis. Can. J. Anim. Sci. 66:157-166. 